\title{
Standard X-Ray Diffraction Patterns
}

\author{
Howard E. Swanson and Eleanor Tatge
}

\begin{abstract}
Improvement of the X-ray diffraction pattern file of the American Society for Testing Materials is the basis for work being done at the National Bureau of Standards with the cooperation of the Joint Committee on Chemical Analysis by X-ray Diffraction Methods of the American Society for Testing Materials, the American Crystallographic Association, and the British Institute of Physics. The equipment used in obtaining the data presented here comprises a Geiger-counter spectrometer with a $180^{\circ}$ arc calibrated with the calculated patterns of substances whose lattice constants are known with high precision. Separate charts are prepared to obtain data for interplanar spacing and intensity measurements so that special attention can be paid to mounting the sample for the best results in each case. Tables are included to compare the patterns with those recorded in the literature.

Tables and discussion follow for X-ray diffraction data based on four compounds not listed in the American Society for Testing Materials file and on four represented there. The patterns of zinc borate, $\mathrm{ZnB}_{2} \mathrm{O}_{4}$; selenium oxide, $\mathrm{SeO}_{2}$; magnesium silicate (forsterite), $\mathrm{Mg}_{2} \mathrm{SiO}_{4}$; and magnesium tungstate, $\mathrm{MgWO}_{4}$, are recommended as additions to the file. The patterns of strontium nitrate, $\mathrm{Sr}\left(\mathrm{NO}_{3}\right)_{2}$; barium nitrate, $\mathrm{Ba}\left(\mathrm{NO}_{3}\right)_{2}$; lead fluochloride (matlockite), $\mathrm{PbFCl}$; and mercuric chloride, $\mathrm{HgCl}_{2}$, are recommended to replace the present patterns in the file.
\end{abstract}

\section{Introduction}

The National Bureau of Standards is undertaking a systematic review of published X-ray powder diffraction patterns and an experimental investigation planned to revise and supplement them. The work is being performed in cooperation with the Joint Committee on Chemical Analysis by X-ray Diffraction Methods, composed of members from the American Society for Testing Materials, the American Crystallographic Association, and the British Institute of Physics. The basis for the work is the card file of X-ray diffraction data published by the ASTM [1]. ${ }^{1}$ The information in the file was assembled from all available sources by a subcommittee, under the chairmanship of W. P. Davey, representing the organizations noted above. Data for inorganic and organic chemicals and minerals, as given in the cards, include interplanar spacings, relative intensities of the diffracted beams, and, where available, planar indices, unit-cell dimensions, specific gravity, and optical properties.

The objectives of the project are to record standard X-ray diffraction patterns for compounds of high purity comparable to the best patterns produced by other types of apparatus for the ASTM file. These patterns are used as a basis for comparing and evaluating duplicate file patterns, and as new information to be added to the file. For this purpose X-ray diffraction equipment utilizing a Geigercounter spectrometer with a $160^{\circ}$ effective arc is used.

Considerable progress has been made since 1920 in the production of X-ray diffraction patterns. In most older patterns the interplanar spacings are fewer in number and the precision of the measurements less than that obtainable with present equipment. In some instances the first low-angle line or lines are missing, and in other cases they do not fit

Figures in brackets indicate the literature references at the end of this paper. the unit-cell dimensions determined from the more accurate high-angle lines or from data obtained by other techniques. In addition, many of the patterns appearing on the ASTM diffraction pattern file cards are combinations of several sets of published and previously unpublished data, and the resulting patterns are consequently difficult to evaluate. The present program to improve and clarify the ASTM file should add to its usefulness.

\section{Equipment}

The spectrometer assembly is based on X-ray equipment of the type designed for film cameras, modified for Geiger-counter recording. A Machlett X-ray tube is mounted horizontally, so that the focal spot has an effective focusing cross section of approximately 1.0 by $0.2 \mathrm{~mm}$. For most work a copper target and nickel filter are used. Two rectifying valves contribute to linear Geiger-counter response. An arc of $180^{\circ}$ was made by joining two $90^{\circ}$ Geigercounter spectrometer ares [2]. The specimen holder is designed to allow oscillation or rotation of the specimen in the plane of its surface to increase the number of contributing crystal particles. The diffracted $\mathrm{X}$-ray beam is received in the Geiger counter as it is moved along the arc by a synchronous motor. The Geiger-counter response represents the diffraction maxima as peaks on a potentiometer chart.

Auxiliary equipment includes a small blower directed on the specimen holder, and, in summer, an air-conditioning unit, which aid in maintaining the temperature of the specimen close to $26^{\circ} \mathrm{C}$. A drybox permits specimens of low stability to be mounted in dry air, or in an atmosphere of nitrogen or helium. Many unstable samples can be mounted satisfactorily as flat specimens if the powder is mixed with enough petrolatum to coat each particle and the mixture smoothed into the holder. Samples that are affected by petrolatum may be sealed into a cell with a thin cellophane window. 
The Geiger-counter diffraction spectrometer is capable of greater precision in determining interplanar spacings if patterns of a few well-known materials are used to construct calibration curves for the full extent of the Geiger-counter arc travel. The unit-cell measurements given by Jette and Foote [3] are particularly useful as a basis for the calculation of spacings suitable for calibration. Aluminum, silver, gold, silicon, and tungsten dimensions are given at $25^{\circ} \mathrm{C}$. Sodium chloride [4] is also a good calibration standard, but the coefficient of expansion is relatively large, so that temperature is a critical factor. Diamond [5] dust is useful because its coefficient of expansion is low enough to be disregarded.

\section{Procedures}

Interplanar spacings and intensity measurements are obtained from separately prepared charts, because the type of sample mount that gives the most precise interplanar spacing data is the one least suitable for satisfactory intensity data.

For the spacing measurements the powder sample is packed flat on a glass slide, where it is confined within a thin plastic ring cemented to the glass. Special care is given to obtaining a smooth flat surface, which facilitates close alinement with the spectrometer center. An error of $0.05 \mathrm{~mm}$ in the position of the specimen surface relative to the spectrometer arc center causes a change in the apparent diffraction angle $2 \theta$ of $0.032^{\circ}$ at $0^{\circ}$ of arc, which decreases to zero at $180^{\circ}$ of arc. Errors due to such surface alinement difficulty may be compensated by corrections based on a few lines from a calibration substance used as an internal standard. Errors due to the penetration of the X-rays into samples containing elements of low atomic number may be corrected in the same manner. A small amount of the standard suffices, as few lines are needed for comparison. Tungsten contributes few lines to complicate the pattern, and its back reflection lines are unusually strong; less than 5 percent of the powder added to the sample is usually sufficient. In running the spacing charts a motor speed of $1 / 2 \mathrm{rpm}$ is used to move the Geiger-counter arm $1 / 2 \%$ min, covering the $160^{\circ}$ of arc in about $5 \mathrm{hr}$. The recorder charts are run so that $1^{\circ}$ of arc is equivalent to 1 in. on the chart paper. The interplanar spacings are obtained from the reflection angles directly by reference to spacing tables [6]. In general, the angles are measured with an accuracy well within $\pm 0.04^{\circ}$. With copper radiation the largest measurable interplanar spacing is $44 \mathrm{~A}$. The definition of the diffraction peaks is such that those due to the $\mathrm{K} \alpha_{1}$ and $\mathrm{K} \alpha_{2}$ wavelengths are usually resolved at angles greater than $70^{\circ}$ with copper radiation.

For intensity measurements an additional chart is run. Random orientation of the crystal particles is achieved by loosely drifting the powdered sample, the particles of which are usually less than $0.025-\mu$ diameter, into a cell fronted by a window of $0.005-$ $\mathrm{mm}$ cellulose acetate. The cell is wide enough to intercept the full width of the X-ray beam at the lowest angles of the pattern and thick enough to accommodate the greatest penetration of $\mathrm{X}$-rays at high angles. For most materials $1 \mathrm{~mm}$ is thick enough. The specimen preparation outlined avoids the packing associated with many types of flat specimen mountings, which usually modifies the peak intensities so that they do not compare well with those made from a randomly oriented cylindrical mounting. In preparing the charts from which the intensity measurements of the patterns given here were made, the Geiger-counter motor was run at 1 rpm. Recent work indicates that a motor speed of $1 / 4$ rpm reproduces peak heights somewhat better. As the amplitude record of the instrument has been found linear for the counting rates used, the heights of the peaks are regarded as close approximations to the actual intensities of the diffracted X-ray beams. Measurements at diffraction angles less than about $70^{\circ}$ include the intensities of both the $\mathrm{K} \alpha_{1}$ and $\mathrm{K} \alpha_{2}$ peaks. The peaks are measured vertically from a base line drawn at background height and are valued relative to the line of strongest intensity. Repeated intensity measurements for the stronger lines are found to vary less than 5 percent with separate samples of the same material. The resulting data are comparable to those from both the DebyeScherrer type of camera and the usual Geigercounter spectrometer procedures, if absorption errors introduced by the round specimen of the first are kept small and if random orientation is attained in the flat specimen of the latter.

Table 1 includes a comparison of intensity measurements from film camera and Geiger-counter equipment. The data for $\mathrm{MgO}$ in column (a) are based on careful film measurements made by Frevel [7], using molybdenum radiation. Column (c) comprises Frevel's calculated intensity values. In columns (b) and (d) both sets were converted to measurements based on copper radiation by means of the conversion chart in the Index to the ASTM diffraction pattern file in order to compare them with the NBS measurements of columns (e) and (f). A portion of a large single crystal of $\mathrm{MgO}$ was ground to pass a 325-mesh sieve. This powder, pressed lightly into the ring on the glass slide, formed a highly oriented specimen. The effect of the pressed sample on the intensity pattern, as shown in column (e), is typical of that of powder mountings used in many laboratories for routine identification with Geiger-counter diffraction equipment. The packing of the crystal particles is influenced by the prominent cleavage of magnesium oxide parallel to 100 , and causes a reflection of considerably higher relative intensity for this plane than occurs with a randomly oriented sample. When the same sample powder was remounted by pouring the powder into the cell used in this laboratory for intensity measurements, the data shown in column (f) were obtained. The agreement of this pattern with Frevel's intensity measurements is well within the limit of the experimental error.

In addition to the tabulated interplanar spacings and intensity measurements, the standard patterns are accompanied by other pertinent data. The 
Miller indices of the diffraction planes are calculated from published unit-cell dimensions. From the indexed lines the unit-cell measurements of the specimen used for the pattern are precisely determined and the density calculated. The phase purity of the specimens is checked by the petrographic microscope, and the indices of refraction of the material are determined when possible. Effort is made to obtain specimens of high purity upon which to base standard patterns, although, in general, small amounts of impurities do not significantly affect the pattern. Indeed, temperature variation may be just as important, for the presence of 0.01 percent of a foreign material in solid solution may produce, at most, a barely perceptible change in the size of the unit cell, whereas the change of a few degrees produces in some materials a substantial difference.

TABLE 1. Comparison of intensity measurements for magnesium oxide

\begin{tabular}{|c|c|c|c|c|c|c|}
\hline \multirow{2}{*}{$\begin{array}{l}\text { Radi- } \\
\text { ation }\end{array}$} & \multicolumn{2}{|c|}{$\begin{array}{c}\text { Film camera, } \\
\text { Frevel }\end{array}$} & \multicolumn{2}{|c|}{$\begin{array}{c}\text { Calculated } \\
\text { values, Frevel }\end{array}$} & \multirow{3}{*}{$\begin{array}{c}\text { Pressed } \\
\text { sample, } \\
\text { highly } \\
\text { oriented, } \\
\text { NBS } \\
\mathrm{Cu} \\
\text { (e) }\end{array}$} & \multirow{3}{*}{$\begin{array}{l}\text { Same } \\
\text { powder as } \\
\text { (e) poured } \\
\text { into cell, } \\
\text { NBS } \\
\mathrm{Cu} \\
\text { (f) }\end{array}$} \\
\hline & \multirow{2}{*}{$\begin{array}{l}\text { Mo } \\
\text { (a) }\end{array}$} & \multirow{2}{*}{$\begin{array}{l}\text { Con- } \\
\text { verted } \\
\text { to Cu } \\
\text { (b) }\end{array}$} & \multirow{2}{*}{$\begin{array}{l}\text { Mo } \\
\text { (c) }\end{array}$} & \multirow{2}{*}{$\begin{array}{l}\text { Con- } \\
\text { verted } \\
\text { to } \mathrm{Cu} \\
\text { (d) }\end{array}$} & & \\
\hline$h k l$ & & & & & & \\
\hline 111 & & & & & 3 & \\
\hline 200 & 100 & 100 & 100 & 100 & 100 & 100 \\
\hline 220 & 50 & 45 & 55 & 50 & 21 & 51 \\
\hline 311 & 4 & 4 & 6 & 6 & 2 & 5 \\
\hline 222 & 12 & 11 & 15 & 13 & 4 & 11 \\
\hline 400 & 4 & 4 & 6 & 6 & 4 & 6 \\
\hline & 1 & 1 & 3 & 4 & & \\
\hline $\begin{array}{l}420 \\
422\end{array}$ & & & & & $\begin{array}{l}6 \\
4\end{array}$ & 12 \\
\hline 511 & & & & 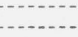 & $\begin{array}{l}4 \\
1\end{array}$ & $\begin{array}{r}11 \\
2\end{array}$ \\
\hline
\end{tabular}

The patterns prepared are checked with all available patterns previously made by other workers. References to the published literature are obtained by systematic search through Wyckoff's compilations [8], the Strukturbericht [9], Chemical Abstracts [10], and the ASTM cards [1]. The type of equipment used, radiation, unit-cell dimensions derived, space groups, density, and other data are noted for comparison. Patterns usually are published in a variety of forms, requiring recalculation for comparison. The values of $\theta, \sin \theta$, or $\sin ^{2} \theta$ may be listed, rather than interplanar spacings. Intensity measurements may be given as absolute values, as relative values on the basis of 1,10 , or 100 for the strongest line, or as visual estimates. In the preparation of the following comparison tables, these are reduced to interplanar spacings, $d$, and relative intensities, $I$, to the base 100 , except that visual estimates not expressed numerically are retained.

Interplanar spacings and unit-cell dimensions for published patterns may appear in $k X$ units or in angstrom units variously defined, depending on the accepted value of the radiation wavelength used at the time the pattern was made, which may or may not be given. In general, the difference is small; however for accurate comparison, the interplanar spacings and unit-cell dimensions are recalculated to the angstrom unit adopter in 1946 [11], which is used for the standard patterns. In tables 2 to 9 the recalculation of published patterns was usually made by dividing the spacings by the wavelength of the radiation originally used and multiplying by the wavelength now in use. In many cases the wavelength was not specified; then for data published between 1930 and 1947 it has been assumed that $k X$ units were employed, and conversion to angstroms was made by use of the factor 1.00202 ; conversion of earlier data without specified radiation wavelengths was not possible, due to the variety of wavelengths in use. The interplanar spacings of each pattern previously published are not rounded off, although in many instances it is plain from the variation in the unit-cell calculations, particularly with cubic patterns, that one or more of the figures is not significant. For the sake of simplicity and uniformity of treatment, the practice was adopted of averaging the unit-cell dimensions from the last five lines, those of smallest interplanar spacing, of any set. This has generally given a serviceable figure. For the tetragonal patterns $a$ was determined from as many $h 00$ and $h k 0$ lines as possible, and the average used to calculate $c$ from the remaining lines. These were averaged after eliminating the more divergent values.

\section{Patterns}

The following X-ray diffraction patterns for exceptionally pure chemicals available to the $\mathrm{Na}$ tional Bureau of Standards were measured. Interplanar spacings and intensities are listed in the accompanying tables, in which they are compared with the results of other investigators. Cubic: Zinc borate, $\mathrm{ZnB}_{2} \mathrm{O}_{4}$; strontium nitrate, $\mathrm{Sr}\left(\mathrm{NO}_{3}\right)_{2}$; barium nitrate, $\mathrm{Ba}\left(\mathrm{NO}_{3}\right)_{2}$. Tetragonal: Lead fluochloride (matlockite), $\mathrm{PbFCl}$; selenium dioxide, $\mathrm{SeO}_{2}$. Orthorhombic: Mercuric chloride, $\mathrm{HgCl}_{2}$; magnesium silicate (forsterite), $\mathrm{Mg}_{2} \mathrm{SiO}_{4}$. Monoclinic: Magnesium tungstate, $\mathrm{MgWO}_{4}$. There are no patterns in the ASTM file for $\mathrm{ZnB}_{2} \mathrm{O}_{4}, \mathrm{SeO}_{2}, \mathrm{Mg}_{2} \mathrm{SiO}_{4}$, or $\mathrm{MgWO}$. It is recommended that the following patterns in the ASTM powder diffraction pattern file be replaced by National Bureau of Standards standard patterns:

\begin{tabular}{|c|c|c|c|c|c|}
\hline Compound & $\begin{array}{l}\text { Old flle } \\
\text { number }\end{array}$ & $\begin{array}{l}\text { New flle } \\
\text { number }\end{array}$ & $\begin{array}{l}\text { Index } \\
\text { lines }\end{array}$ & Author & Year \\
\hline $\mathrm{Sr}\left(\mathrm{NO}_{3}\right)_{2 \ldots} \ldots$ & 732 & $\left\{\begin{array}{r}0733 \\
1-0336 \\
1-0336\end{array}\right.$ & $\begin{array}{l}4.50 \\
2.35 \\
2.24\end{array}$ & $\begin{array}{l}\text { Hanawalt, Rinn, and } \\
\text { Frevel. }\end{array}$ & 1938 \\
\hline $\mathrm{Ba}\left(\mathrm{NO}_{3}\right)_{2} \ldots$ & 2923 & $\begin{array}{r}3111 \\
1-1144 \\
1-1144\end{array}$ & $\begin{array}{l}\text { 2. } 44 \\
\text { 4. } 69 \\
2.34\end{array}$ & do & 1938 \\
\hline $\mathrm{PbFCl}_{\ldots}$ & II- 856 & $\begin{array}{r}1310 \\
2-0388 \\
2-0377\end{array}$ & $\begin{array}{l}3.54 \\
2.25 \\
1.77\end{array}$ & British Museum ...... & \\
\hline $\mathrm{PbFCl}$ & & $\begin{array}{r}3928 \\
3-1184 \\
3-1182\end{array}$ & $\begin{array}{l}\text { 1. } 22 \\
\text { 1. } 29 \\
\text { 1. } 79\end{array}$ & $\left\{\begin{array}{l}\text { Nieuwenkamp and } \\
\text { Bijvoet. }\end{array}\right.$ & 1932 \\
\hline $\mathrm{HgCl}_{2 \ldots} \ldots$ & 812 & $\begin{array}{r}0852 \\
1-0377 \\
1-0365\end{array}$ & $\begin{array}{l}\text { 4. } 35 \\
\text { 3. } 00 \\
2.70\end{array}$ & $\begin{array}{l}\text { Hanawalt, Rinn, and } \\
\text { Frevel. }\end{array}$ & 1938 \\
\hline $\mathrm{HgCl}_{2 \ldots}$ & II- -524 & $\begin{array}{r}0826 \\
2-0249 \\
2-0255\end{array}$ & $\begin{array}{l}4.34 \\
4.08 \\
3.36\end{array}$ & Bräkken and Harang. & 1928 \\
\hline
\end{tabular}




\section{Zinc Borate, $\mathrm{ZnB}_{2} \mathrm{O}_{4}$}

No published pattern for zinc borate was found. The sample used for the pattern of table 2 was one of the phosphor preparations of the Radio Corporation of America [12], sample XII-17, of high purity. The unit-cell edge derived from an average of the values obtained from the last five lines is $7.4726 \mathrm{~A}$, at $26^{\circ} \mathrm{C}$. The lattice derived from the powder pattern is body-centered cubic, with two molecules in the unit cell. The density is 1.2017 , from the X-ray data. The index of refraction for the sample was determined as 1.739 .

TABLE 2. Zinc borate: $\mathrm{ZnB}_{2} \mathrm{O}_{4}$

Copper radiation, $\lambda=1.5405$. Temperature, $26^{\circ} \mathrm{C}$

\begin{tabular}{|c|c|c|c|c|c|c|c|}
\hline$h k l$ & $d$ & $I$ & $a$ & $h k l$ & $d$ & $I$ & $a$ \\
\hline 110 & 5. 29 & 6 & 7.48 & 444 & 1.0788 & 1 & 7. 474 \\
\hline 200 & 3.74 & 3 & 7.48 & 710 & 1. 0568 & 1 & 7.473 \\
\hline 211 & 3. 048 & 100 & 7. 466 & 640 & 1. 0365 & 1 & 7. 474 \\
\hline & & & & & & & \\
\hline $\begin{array}{l}310 \\
222\end{array}$ & $\begin{array}{l}2.364 \\
2.158\end{array}$ & $\begin{array}{r}25 \\
1\end{array}$ & 7.476 & 642 & $\begin{array}{l}1.0109 \\
0.9991\end{array}$ & $\begin{array}{l}5 \\
1\end{array}$ & 7.477 \\
\hline 321 & 1.997 & 20 & 7. 472 & 730 & .9812 & 2 & 7. 4726 \\
\hline 400 & 1.869 & 13 & 7. 476 & 732 & .9490 & 1 & 7. 4724 \\
\hline 411 & 1.761 & 38 & 7.471 & 811 & 9198 & 3 & 7. 4725 \\
\hline 420 & 1. 672 & 2 & 7. 477 & 820 & .9062 & 1 & 7. 4727 \\
\hline 332 & 1. 594 & 3 & 7. 477 & 653 & .8932 & 1 & 7. 4730 \\
\hline 422 & 1. 526 & 25 & 7. 476 & 822 & .8807 & 1 & 7. 4730 \\
\hline 510 & 1.466 & 5 & 7.475 & 831 & .8687 & 3 & 7. 4728 \\
\hline 521 & 1. 364 & 8 & 7. 471 & 662 & .8573 & 1 & 7. 4738 \\
\hline 440 & 1. 321 & 4 & 7. 473 & 752 & .8462 & 1 & 7. 4734 \\
\hline 530 & 1. 282 & 3 & 7. 475 & 910 & .8252 & 1 & 7.4725 \\
\hline 600 & 1. 246 & 1 & 7. 476 & 842 & .8153 & 1 & 7. 4723 \\
\hline 611 & 1. 213 & 2 & 7. 477 & 921 & .8058 & 1 & 7. 4727 \\
\hline 620 & 1. 1817 & 1 & 7. 474 & 664 & .7996 & 1 & 7. 4728 \\
\hline \multirow{3}{*}{$\begin{array}{l}541 \\
631\end{array}$} & 1. 1531 & 3 & 7.473 & 930 & .7877 & 1 & 7. 4728 \\
\hline & 1. 1025 & 1 & 7. 478 & & & & \\
\hline & & & & \multicolumn{3}{|c|}{ A verage last 5 lines } & 7. 4726 \\
\hline
\end{tabular}

\section{Strontium Nitrate, $\mathrm{Sr}\left(\mathrm{NO}_{3}\right)_{2}$}

A pattern for strontium nitrate is compared in table 3 with two previously published patterns. The first, by Vegard [13] in 1922, was well indexed and misses few lines, although it is of less precision than the later patterns. The copper radiation used was assigned a wavelength of $1.54 \mathrm{~A}$, close to the currently accepted value for the angstrom. The data were published as $\sin \theta$ values and estimated intensities. The former were converted to interplanar spacings for table 3 . The pattern by Hanawalt, Rinn, and Frevel [14], 1938, is included in the diffraction pattern file of the ASTM. It was obtained with molybdenum radiation with the wavelength given as $0.708 k X$. The sample for the National Bureau of Standards pattern was a specially purified material supplied by the Mallinckrodt Chemical Works. A spectrographic analysis shows $\mathrm{Ba}<0.01$ percent and $\mathrm{Na}<0.01$ percent as the only impurities greater than traces.

From the intensity measurements of the NBS pattern, the three strongest lines are the 111, 311, and 222 , consistent with the index lines of the ASTM card for the Hanawalt, Rinn, and Frevel pattern. The unit-cell edges derived for the three patterns, $7.81,7.799$, and $7.779 \mathrm{~A}$, show considerable variation. Other published unit-cell determinations in-
Table 3. Strontium Nitrate: $\mathrm{Sr}\left(\mathrm{NO}_{3}\right)_{2}$

\begin{tabular}{|c|c|c|c|c|c|c|c|c|c|}
\hline \multirow[b]{2}{*}{$h k l$} & \multicolumn{3}{|c|}{$\begin{array}{c}\text { 1922, } \\
\text { Vegard } \\
\text { C11, 1.54 A }\end{array}$} & \multicolumn{3}{|c|}{$\begin{array}{c}1938 \\
\text { Hanawalt, Rinn } \\
\text { and Frevel } \\
\text { Mo, } 0.709 \mathrm{~A}\end{array}$} & \multicolumn{3}{|c|}{$\begin{array}{c}1951, \\
\text { Swanson and Tatge } \\
\mathrm{Cu}, 1.5495 \mathrm{~A} \\
26^{\circ} \mathrm{C}\end{array}$} \\
\hline & $d$ & $I$ & $a$ & $d$ & $I$ & $a$ & $d$ & $I$ & $a$ \\
\hline $\begin{array}{l}111 \\
200 \\
210 \\
211 \\
220\end{array}$ & $\begin{array}{l}\text { 4. } 54 \\
\text { 3. } 92 \\
\text { 3. } 53 \\
\text { 3. } 22 \\
\text { 2. } 78\end{array}$ & $\begin{array}{l}\mathrm{m} \\
\mathrm{m} \\
\mathrm{w} \\
\mathrm{w} \\
\mathrm{w}\end{array}$ & $\begin{array}{l}\text { 7. } 86 \\
7.84 \\
7.89 \\
7.89 \\
7.87\end{array}$ & $\begin{array}{l}4.51 \\
3.92 \\
3.49 \\
3.19 \\
-.+\end{array}$ & $\begin{array}{r}100 \\
33 \\
33 \\
33\end{array}$ & $\begin{array}{r}7.81 \\
7.84 \\
7.80 \\
7.81 \\
\end{array}$ & $\begin{array}{l}\text { 4. } 48 \\
\text { 3. } 88 \\
\text { 3. } 474 \\
\text { 3. } 175 \\
\text { 2. } 749\end{array}$ & $\begin{array}{r}100 \\
13 \\
21 \\
14 \\
19\end{array}$ & $\begin{array}{l}7.76 \\
7.76 \\
7.768 \\
7.777 \\
7.775\end{array}$ \\
\hline $\begin{array}{l}311 \\
222 \\
400 \\
411 \\
331\end{array}$ & $\begin{array}{l}2.37 \\
2.27 \\
1.96\end{array}$ & $\begin{array}{l}\mathrm{s} \\
\mathrm{s} \\
\mathrm{m}\end{array}$ & $\begin{array}{l}\text { 7. } 86 \\
7.85 \\
7.84\end{array}$ & $\begin{array}{l}2.36 \\
2.24 \\
1.94\end{array}$ & $\begin{array}{r}100 \\
100 \\
17\end{array}$ & $\begin{array}{l}\text { 7. } 83 \\
7.76 \\
7.76\end{array}$ & $\begin{array}{l}\text { 2. } 346 \\
\text { 2. } 246 \\
\text { 1. } 945 \\
\text { 1. } 836 \\
\text { 1. } 785\end{array}$ & $\begin{array}{r}72 \\
54 \\
12 \\
2 \\
16\end{array}$ & $\begin{array}{l}\text { 7. } 781 \\
\text { 7. } 780 \\
\text { 7. } 780 \\
\text { 7. } 789 \\
\text { 7. } 781\end{array}$ \\
\hline $\begin{array}{l}420 \\
422 \\
333 \\
521 \\
440\end{array}$ & $\begin{array}{l}1.75 \\
1.60 \\
1.51\end{array}$ & $\begin{array}{l}\mathrm{m} \\
\mathrm{m} \\
\mathrm{m}\end{array}$ & $\begin{array}{l}7.84 \\
7.81 \\
7.84\end{array}$ & $\begin{array}{l}1.75 \\
1.58 \\
1.50 \\
1.379\end{array}$ & $\begin{array}{l}17 \\
17 \\
17\end{array}$ & $\begin{array}{l}\text { 7. } 83 \\
7.74 \\
\text { 7. } 79\end{array}$ & $\begin{array}{l}\text { 1. } 740 \\
\text { 1. } 589 \\
\text { 1. } 498 \\
\text { 1. } 420 \\
\text { 1. } 376\end{array}$ & $\begin{array}{r}12 \\
10 \\
12 \\
2 \\
11\end{array}$ & $\begin{array}{l}\text { 7. } 782 \\
7.784 \\
7.784 \\
7.778 \\
7.784\end{array}$ \\
\hline $\begin{array}{l}531 \\
600 \\
620 \\
533 \\
622\end{array}$ & $\begin{array}{l}\text { 1. } 32 \\
\text { 1. } 30 \\
\text { 1. } 24 \\
\text { 1. } 20 \\
\text { 1. } 176\end{array}$ & $\begin{array}{l}\mathrm{s} \\
\mathrm{W} \\
\mathrm{W} \\
\mathrm{m} \\
\mathrm{m}\end{array}$ & $\begin{array}{l}7.83 \\
7.81 \\
7.82 \\
7.84 \\
7.80\end{array}$ & 1.318 & 17 & \begin{tabular}{r}
7.797 \\
\hdashline \\
\end{tabular} & $\begin{array}{l}\text { 1. } 315 \\
1.296 \\
1.231 \\
1.1867 \\
1.1736\end{array}$ & $\begin{array}{r}10 \\
4 \\
2 \\
4 \\
1\end{array}$ & $\begin{array}{l}\text { 7. } 780 \\
7.776 \\
7.786 \\
7.782 \\
7.785\end{array}$ \\
\hline $\begin{array}{l}444 \\
711 \\
642 \\
731 \\
732\end{array}$ & $\begin{array}{l}1.128 \\
\text { 1. } 094 \\
\text { 1. } 045 \\
\text { 1. } 017\end{array}$ & $\begin{array}{c}\mathrm{w} \\
\mathrm{m} \\
\mathrm{m} \\
\mathrm{s}\end{array}$ & $\begin{array}{l}7.82 \\
7.81 \\
7.82 \\
7.81 \\
\end{array}$ & & & & $\begin{array}{l}1.1235 \\
1.0893 \\
1.0396 \\
1.0128 \\
0.9878\end{array}$ & $\begin{array}{l}2 \\
3 \\
3 \\
5 \\
2\end{array}$ & $\begin{array}{l}7.784 \\
7.779 \\
7.780 \\
7.780 \\
7.778\end{array}$ \\
\hline $\begin{array}{l}820 \\
422 \\
751 \\
840 \\
911 \\
842 \\
664\end{array}$ & $\begin{array}{r}0.951 \\
.927 \\
.902 \\
.873 \\
.857 \\
.851 \\
.833\end{array}$ & $\begin{array}{c}\mathrm{s} \\
\mathrm{s} \\
\mathrm{s} \\
\mathrm{m} \\
\mathrm{s} \\
\mathrm{s} \\
\mathrm{w}\end{array}$ & $\begin{array}{l}7.84 \\
7.86 \\
7.81 \\
7.80 \\
7.81 \\
7.80 \\
7.81\end{array}$ & & & & $\begin{array}{r}.9435 \\
.9168 \\
.8983 \\
\end{array}$ & $\begin{array}{c}4 \\
4 \\
5 \\
- \\
-. \\
-.\end{array}$ & \begin{tabular}{r} 
7. 780 \\
7.779 \\
7.780 \\
\hdashline \\
\end{tabular} \\
\hline \multicolumn{3}{|c|}{$\begin{array}{l}\text { Average unit-cell } \\
\text { edge from last } \\
5 \text { lines.... }\end{array}$} & 7.81 & & & a 7.799 & & & 7. 779 \\
\hline
\end{tabular}

a Average of last 2 lines only.

clude 7.80 A, by Jaeger and Van Melle [15] in 1928, given without stating the radiation used; and 7.811 A by Ringdal [16] in 1932, measured from a chart showing unit-cell variations in solid solutions, iron radiation, and with no wavelength given. Vegard and Roer [17] in 1942, studying the coefficient of expansion of nitrates, gave the unit-cell dimension of strontium nitrate at $10^{\circ} \mathrm{C}$ as $7.7629 \mathrm{~A}$, the coefficient of expansion between $10^{\circ}$ and $70^{\circ}$ as $2.58 \times 10^{-5}$. They state that the unit-cell edge of sodium chloride used for calibration was $5.628 \mathrm{~A}$. Thus, assuming that the values of Ringdal and of Vegard and Roer are in $k X$ units, the following table shows comparative values, after conversion to angstroms:

Unit-cell dimensions, angstroms

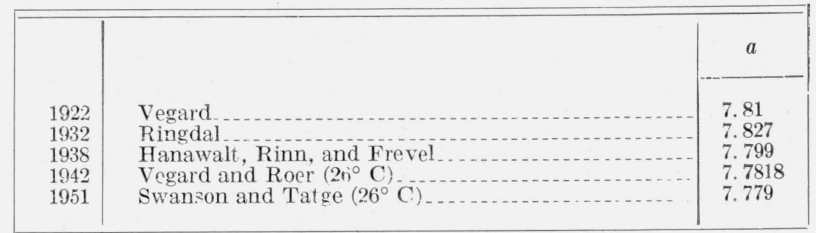

The lattice of strontium nitrate is simple cubic, four molecules to the unit cell. The space group according to Jaeger and Van Melle is $T_{h}^{6}(\mathrm{~Pa} 3)$; Vegard and Bilberg [16] confirm this, but indicate 
the possibility of $T^{4}\left(P 2_{1} 3\right)$. The patterns of table 3 show $h k 0$ only if $h$ is even, adding confirmation of the $T_{h}^{6}$ (Pa3) group. The density from the NBS unit-cell edge value is 2.974 . The index of refraction is 1.587 .

\section{Barium Nitrate, $\mathrm{Ba}\left(\mathrm{NO}_{3}\right)_{2}$}

The pattern for barium nitrate closely parallels that for strontium nitrate. Vegard [13] and Hanawalt, Rinn, and Frevel [14] published patterns, of which the latter is included in the ASTM file. In Vegard's paper the copper radiation was assigned, as for his strontium nitrate pattern, a wavelength of $1.54 \mathrm{~A}$, and the data were published as $\sin \theta$ values. For comparison with the data in table 4, they were converted to interplanar spacings. Hanawalt, Rinn, and Frevel used molybdenum radiation with a wavelength of $0.708 \mathrm{kX}$, converted in table 4 to 0.709 A. The National Bureau of Standards sample was specially purified material supplied by

TABLE 4. Barium nitrate: $\mathrm{Ba}\left(\mathrm{NO}_{3}\right)_{2}$

\begin{tabular}{|c|c|c|c|c|c|c|c|c|c|}
\hline \multirow[b]{2}{*}{$h k l$} & \multicolumn{3}{|c|}{$\begin{array}{c}1922 \\
\text { Vegard } \\
\mathrm{Cu}, 1.54 \mathrm{~A}\end{array}$} & \multicolumn{3}{|c|}{$\begin{array}{c}1938 \\
\text { Hanawalt, Rinn and } \\
\text { Frevel } \\
\text { Mo, } 0.709 \mathrm{~A}\end{array}$} & \multicolumn{3}{|c|}{$\begin{array}{c}1951 \\
\text { Swanson and Tatge } \\
\mathrm{Cu}, 1.5405 \mathrm{~A}, 26^{\circ} \mathrm{C}\end{array}$} \\
\hline & $d$ & $I$ & $a$ & $d$ & $I$ & $a$ & $d$ & $I$ & $a$ \\
\hline $\begin{array}{l}111 \\
200 \\
210 \\
211 \\
220\end{array}$ & $\begin{array}{l}\text { 4. } 70 \\
\text { 3. } 93\end{array}$ & $\begin{array}{l}\mathrm{S} \\
\mathrm{S}\end{array}$ & $\begin{array}{l}8.14 \\
7.86\end{array}$ & $\begin{array}{l}\text { 4. } 70 \\
\text { 4. } 07 \\
\text { 3. } 63 \\
\text { 3. } 32 \\
\text { 2. } 88\end{array}$ & $\begin{array}{l}75 \\
30 \\
15 \\
10 \\
40\end{array}$ & $\begin{array}{l}8.14 \\
8.14 \\
8.12 \\
8.13 \\
8.15\end{array}$ & $\begin{array}{l}\text { 4. } 68 \\
\text { 4. } 06 \\
\text { 3. } 63 \\
\text { 3. } 313 \\
\text { 2. } 870 .\end{array}$ & $\begin{array}{l}95 \\
40 \\
11 \\
14 \\
35\end{array}$ & $\begin{array}{l}\text { 8. } 11 \\
8.12 \\
8.12 \\
8.115 \\
8.118\end{array}$ \\
\hline $\begin{array}{l}311 \\
222 \\
400 \\
411 \\
331\end{array}$ & $\begin{array}{l}2.45 \\
2.34 \\
2.03\end{array}$ & $\begin{array}{c}\text { vs } \\
\mathrm{s} \\
\mathrm{m}\end{array}$ & $\begin{array}{l}8.13 \\
8.11 \\
8.12\end{array}$ & $\begin{array}{l}2.45 \\
2.35 \\
2.02\end{array}$ & $\begin{array}{r}100 \\
50 \\
20\end{array}$ & $\begin{array}{l}8.13 \\
8.14 \\
8.08\end{array}$ & $\begin{array}{l}2.448 \\
2.343 \\
2.029 \\
1.914 \\
1.862\end{array}$ & $\begin{array}{r}100 \\
55 \\
17 \\
21 \\
21\end{array}$ & $\begin{array}{l}8.119 \\
8.116 \\
8.116 \\
8.120 \\
8.116\end{array}$ \\
\hline $\begin{array}{l}420 \\
422 \\
333 \\
440 \\
531\end{array}$ & $\begin{array}{l}\text { 1. } 81 \\
\text { 1. } 66 \\
\text { 1. } 56 \\
\text { 1. } 44 \\
\text { 1. } 37\end{array}$ & $\begin{array}{l}\mathrm{m} \\
\mathrm{m} \\
\mathrm{m} \\
\mathrm{m} \\
\mathrm{vs}\end{array}$ & $\begin{array}{l}8.09 \\
8.13 \\
8.11 \\
8.15 \\
8.11\end{array}$ & $\begin{array}{l}\text { 1. } 81 \\
\text { 1. } 65 \\
\text { 1. } 56 \\
\text { 1. } 436 \\
\text { 1. } 373\end{array}$ & $\begin{array}{l}30 \\
30 \\
30 \\
15 \\
40\end{array}$ & $\begin{array}{l}8.09 \\
8.08 \\
8.11 \\
8.123 \\
8.123\end{array}$ & $\begin{array}{l}\text { 1. } 815 \\
\text { 1. } 657 \\
\text { 1. } 562 \\
\text { 1. } 435 \\
1.372\end{array}$ & $\begin{array}{r}20 \\
15 \\
15 \\
5 \\
18\end{array}$ & $\begin{array}{l}8.117 \\
8.118 \\
8.116 \\
8.118 \\
8.117\end{array}$ \\
\hline $\begin{array}{l}600 \\
611 \\
620 \\
533 \\
622\end{array}$ & 1. 23 & $\mathrm{~m}$ & 8.16 & $\begin{array}{l}\text { 1. } 354 \\
\text { 1. } 321 \\
\text { 1. } 283 \\
\text { 1. } 240 \\
\text { 1. } 224\end{array}$ & $\begin{array}{r}10 \\
1 \\
8 \\
13 \\
13\end{array}$ & $\begin{array}{l}8.124 \\
8.143 \\
8.114 \\
8.131 \\
8.119\end{array}$ & $\begin{array}{l}\text { 1. } 284 \\
\text { 1. } 238 \\
\text { 1. } 224\end{array}$ & $\begin{array}{l}1 \\
1 \\
2\end{array}$ & $\begin{array}{l}8.121 \\
8.118 \\
8.119\end{array}$ \\
\hline $\begin{array}{l}444 \\
711 \\
640 \\
642 \\
731\end{array}$ & 1.17 & $\mathrm{w}$ & N & $\begin{array}{l}\text { 1. } 172 \\
\text { 1. } 139 \\
\text { 1. } 128 \\
\text { 1. } 087 \\
\text { 1. } 058\end{array}$ & $\begin{array}{r}4 \\
10 \\
6 \\
13 \\
20\end{array}$ & $\begin{array}{l}8.120 \\
8.134 \\
8.134 \\
8.134 \\
8.127\end{array}$ & $\begin{array}{l}1.1721 \\
1.1370 \\
1.1261 \\
1.0849 \\
1.0566\end{array}$ & $\begin{array}{l}2 \\
3 \\
1 \\
1 \\
5\end{array}$ & $\begin{array}{l}8.121 \\
8.120 \\
8.120 \\
8.119 \\
8.116\end{array}$ \\
\hline $\begin{array}{l}800 \\
733 \\
820 \\
822 \\
751\end{array}$ & & & & & & & $\begin{array}{r}1.0150 \\
0.9918 \\
.9843 \\
.9567 \\
.9374\end{array}$ & $\begin{array}{l}1 \\
1 \\
1 \\
1 \\
3\end{array}$ & $\begin{array}{l}8.120 \\
8.118 \\
8.117 \\
8.118 \\
8.118\end{array}$ \\
\hline $\begin{array}{l}662 \\
840 \\
911 \\
842 \\
931\end{array}$ & & & & & & & $\begin{array}{l}.9312 \\
.9078 \\
.8911 \\
.8858 \\
.8512\end{array}$ & $\begin{array}{l}1 \\
1 \\
7 \\
3 \\
4\end{array}$ & $\begin{array}{l}8.118 \\
8.120 \\
8.118 \\
8.119 \\
8.120\end{array}$ \\
\hline $\begin{array}{r}933 \\
10.2 .0\end{array}$ & & & & & & & $\begin{array}{l}.8159 \\
.7960\end{array}$ & $\begin{array}{l}5 \\
3\end{array}$ & $\begin{array}{l}8.118 \\
8.118\end{array}$ \\
\hline $\begin{array}{r}\text { A ver } \\
\text { ed } \\
\text { fir }\end{array}$ & $\begin{array}{l}\text { e un } \\
\text { fron } \\
\text { ines. }\end{array}$ & $\begin{array}{l}t \text { cell } \\
\text { last }\end{array}$ & 8.14 & & & 8. 130 & & & 8.119 \\
\hline
\end{tabular}

the Mallinckrodt Chemical Works. Spectrographic analysis indicates the following impurities: $\mathrm{Al}<0.01$ percent, $\mathrm{Na}<0.01$ percent, and $\mathrm{Sr}<0.01$ percent. Copper radiation with a wavelength of $1.54050 \mathrm{~A}$ was used.

The three strongest lines, used as index lines for the ASTM cards, are the same for the NBS and the Hanawalt, Rinn, and Frevel patterns: 311, 111, and 222 lines. The unit-cell edges derived for the three patterns compared in table 4 are $8.14,8.130$, and 8.119 A, respectively. Other published unit-cell determinations include $8.10 \mathrm{~A}$ by Jaeger and Van Melle [15] in 1928, radiation not stated; 8.111 by Ringdal [16] in 1932, measured from a chart showing unit-cell variations in solid solutions, iron radiation, no wavelength given. Vegard and Roer [17] in 1942, studying the coefficient of expansion of nitrates, gave the unit-cell dimension of barium nitrate at $10^{\circ} \mathrm{C}$ as $8.0985 \mathrm{~A}$, the coefficient of expansion between $10^{\circ}$ and $70^{\circ}$ as $1.75 \times 10^{-5}$. They state that the unit-cell edge of sodium chloride used for calibration was 5.628 A. Assuming that the values of Ringdal and of Vegard and Roer are in $k X$ units, the following table compares the various lattice constants after converting them to angstrom units :

Unit-cell dimensions, angstroms

\begin{tabular}{|c|c|c|}
\hline & & $a$ \\
\hline 1922 & Vegard & 8.14 \\
\hline 1932 & 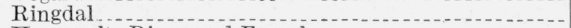 & 8.127 \\
\hline 1938 & Hanawalt, Rinn, and Frevel & 8.130 \\
\hline 1942 & Vegard and Roer $\left(26^{\circ} \mathrm{C}\right)$ & 8. 1172 \\
\hline 1951 & Swanson and Tatge $\left(26^{\circ} \mathrm{C}\right)$ & 8.119 \\
\hline
\end{tabular}

The lattice of barium nitrate is, like that of strontium nitrate, simple cubic, four molecules to the unit cell. As found for strontium nitrate, the patterns of table 4 confirm the determination of the space group $T_{h}^{6}$ (Paß) by Jaeger and Van Melle [15] and by Vegard and Bilberg [18]. The density calculated from the NBS unit-cell edge dimension is 3.244. The index of refraction is 1.570 .

\section{Lead Fluochloride, $\mathrm{PbFCl}$}

The new ASTM X-ray diffraction file includes two patterns for lead fluochloride, one, also in the old file, of natural matlockite from the type locality of Matlock, Derbyshire, Eng., furnished by the British Museum (Natural History), London, the other, in the second supplement, from artificial material, published in 1932 by Nieuwenkamp and Bijvoet [19]. In 1933 Nieuwenkamp [20] compared the patterns of matlockite, whose formula was then given as $\mathrm{Pb}_{2} \mathrm{OCl}_{2}$, and artificial $\mathrm{PbFCl}$, showing their identity. In table 5 these two patterns are compared with one prepared at this Bureau from material of high purity obtained from the NBS chemical laboratory, which had been prepared as part of a project for the precise determination of fluorine compounds. 
TABle 5. Lead fluochloride: $\mathrm{PbFCl}$

\begin{tabular}{|c|c|c|c|c|c|c|}
\hline \multirow[b]{2}{*}{$h k l$} & \multicolumn{2}{|c|}{$\begin{array}{c}1932 \\
\text { Nieuwenkamp } \\
\text { and Bijvoet } \\
\text { Cr, } 2.290\end{array}$} & \multicolumn{2}{|c|}{$\begin{array}{c}\text { No date } \\
\text { British Museum }\end{array}$} & \multicolumn{2}{|c|}{$\begin{array}{c}1951 \\
\text { Swanson and } \\
\text { Tatge } \\
\mathrm{Cu}, 1.5405,26^{\circ} \mathrm{C}\end{array}$} \\
\hline & $d$ & $I$ & $d$ & 1 & $d$ & 1 \\
\hline 001 & & .... & 7.2 & 40 & 7.22 & 20 \\
\hline 002 & & & & & 3. 61 & 70 \\
\hline 101 & 3.58 & 48 & 3.55 & 100 & 3.56 & 100 \\
\hline 110 & 2. 905 & 28 & 2.90 & 70 & 2. 904 & 47 \\
\hline 102 & 2. 719 & 28 & 2. 70 & 70 & 2. 714 & 35 \\
\hline 003 & 2. 410 & 6 & 2.40 & 20 & 2. 409 & 6 \\
\hline 112 & 2. 262 & 51 & 2.25 & 80 & 2. 263 & 38 \\
\hline 103 & 2. 074 & 20 & 2.07 & 70 & 2. 079 & 14 \\
\hline 200 & 2. 052 & 34 & 1.99 & 60 & 2. 053 & 24 \\
\hline 201 & 1. 954 & 23 & 1. 98 & 40 & 1. 974 & 1 \\
\hline 113 & 1. 852 & 17 & 1.84 & 60 & 1.855 & 4 \\
\hline 004 & & & & & 1. 808 & 1 \\
\hline 211 & 1. 780 & 66 & 1. 77 & 80 & 1. 780 & 36 \\
\hline 104 & 1. 654 & 40 & 1. 65 & 70 & 1. 654 & 11 \\
\hline 212 & 1. 635 & 28 & 1. 63 & 60 & 1. 637 & 7 \\
\hline 203 & 1. 560 & 14 & 1. 558 & 20 & 1. 564 & 1 \\
\hline 213 & 1. 462 & 31 & 1. 461 & 60 & 1. 461 & 4 \\
\hline 220 & & 34 & & & 1. 452 & 3 \\
\hline 005 & $\begin{array}{l}1.447 \\
1.417\end{array}$ & $\begin{array}{l}34 \\
37\end{array}$ & 1. 443 & 60 & 1.448 & 1 \\
\hline 221 & & & 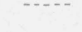 & ..... & ...... & . \\
\hline 105 & 1. 363 & 23 & $\ldots$ & ..... & -....... & $\ldots$ \\
\hline $\begin{array}{l}222 \\
301\end{array}$ & 1. 344 & 66 & 1. 343 & 60 & 1. 346 & 3 \\
\hline 310 & 1. 298 & 68 & ..... & ..... & 1. 299 & 4 \\
\hline 115 & ....... & -.... & ..... & ...... & 1. 293 & 3 \\
\hline 214 & 1. 285 & 89 & $\ldots$ & $\ldots$ & 1. 289 & 5 \\
\hline $\begin{array}{l}302 \\
311\end{array}$ & 1. 281 & 17 & 1. 276 & 70 & 1. 281 & 1 \\
\hline $\begin{array}{l}511 \\
223\end{array}$ & & & 1. 240 & 20 & 1. 244 & 1 \\
\hline 312 & 1. 220 & 100 & 1. 222 & 60 & 1. 223 & 2 \\
\hline 006 & & -.... & $\ldots$ & , & 1. 2041 & 1 \\
\hline 203 & $\ldots$ & . & ...... & . & 1. 1911 & 2 \\
\hline 205 & ..... & ..... & 1. 181 & 60 & 1. 1826 & 2 \\
\hline 106 & - n & - & 1. 156 & 60 & 1. 1565 & 2 \\
\hline 313 & . & 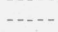 & 1. 142 & 40 & 1. 1443 & $\overline{2}$ \\
\hline 320 & & & & & 1. 1386 & 1 \\
\hline 321 & - . . & . & 1. 126 & 50 & 1. 1254 & 1 \\
\hline 304 & ..... & ..... & & & 1. 0922 & 1 \\
\hline 322 & ..... & .... & 1. 089 & 50 & 1. 0863 & 1 \\
\hline 323 & ..... & .... & $\ldots$ & ..... & 1.0300 & 1 \\
\hline 400 & & & 1.027 & 60 & 1. 0265 & 1 \\
\hline 216 & - & - & 1. 008 & 60 & 1. 0078 & 2 \\
\hline 402 & .... & .... & ..... & ...... & 0. 9872 & 2 \\
\hline 117 & $\ldots$ & - & -.... & ..... & .9735 & 1 \\
\hline 330 & $\ldots$ & .... & ..... & ..... & .9664 & 2 \\
\hline 324 & & & & & .9639 & 3 \\
\hline 412 & . & ....... & $\ldots$ & $\ldots$ & .9608 & 2 \\
\hline 207 & .... & . & $\ldots$ & $\ldots$ & .9223 & 1 \\
\hline 413 & ..... & - . - & -... & - & .9203 & 1 \\
\hline 420 & ..... & -.... & .... & , n... & .9185 & 2 \\
\hline
\end{tabular}

Chromium radiation was used for the Nieuwenkamp and Bijvoet pattern, but the wavelength is not recorded. The data published do not include interplanar spacings; for table 5 they were calculated from the $\sin ^{2} \theta$ values listed, using the wavelength $2.2896 \mathrm{~A}$ for chromium radiation. The interplanar spacings of the British Museum pattern, presumably in $k X$ units, were multiplied by the conversion factor 1.002 for recording in angstroms. While the interplanar spacings of the patterns check closely, the intensity measurements vary. The NBS and British Museum patterns agree that 101 is the strongest line, but the Nieuwenkamp and Bijvoet pattern shows the last line (312) strongest, with the second and third strongest in close proximity. The
002, the second strongest line of the NBS pattern, is unresolved in the others. The third and fourth strongest lines of the NBS pattern appear as second and third strongest in the British Museum pattern. The intensity measurements of the latter show effects due to absorption and to variable focusing common with the Debye-Scherrer procedure when using long wavelength radiation.

Frevel, Rinn, and Anderson [21] in 1946 repeated the 1932 Nieuwenkamp and Bijvoet determination of $a=4.09, c=7.21 \mathrm{kX}$, which, converted to angstroms compares thus with the NBS determination:

Unit-cell dimensions, angstroms

\begin{tabular}{|c|c|c|c|}
\hline & & $a$ & $c$ \\
\hline 1932 & Nieuwenkamp and Bijvoct. & 4. 09 & 7. 21 \\
\hline 1951 & Swanson and Tatge $\left(26^{\circ} \mathrm{C}\right)$ & 4.106 & 7.23 \\
\hline
\end{tabular}

Bannister [22] in 1934 gave the structure as tetragonal, space group $D_{4 h}^{\gamma}($ Pnmm $)$, two molecules in the unit cell, indices of refraction $\omega_{D}=3.145, \epsilon_{D}=2.006$. The NBS pattern yields a density of 7.13 . The sample was too finely powdered for us to determine the indices of refraction.

\section{Selenium Dioxide, $\mathrm{SeO}_{2}$}

A pattern was prepared from specially purified material supplied by the Mallinckrodt Chemical Works. Spectrographic analysis showed no impurities greater than 0.001 percent. The lines are indexed in accordance with the structure and unit-cell dimensions determined by McCullough [23] in 1937. The material is hygroscopic; lines from the monohydrate are omitted from the pattern given in table 6 . Although the crystals generally have been described as monoclinic [24], the NBS pattern confirms the work of McCullough, showing a tetragonal structure. McCullough gives the unit cell dimensions $a=8.353$, $c=5.051$, the probable space group $D_{14}^{13}(P / / m b c)$, or $C_{4 v}^{8}(C 4 c b)$, with eight molecules in the unit cell. Frevel, Rinn, and Anderson [21] in 1946 used these same values. An average of 13 cell-edge values based on $h k 0$ lines yields $a=8.35 \mathrm{~A}$ for the NBS pattern; an average of 11 values for $c$, after eliminating the more divergent ones, yields 5.08 A. Converting the McCullough values to angstrom units, they compare with the NBS determinations as follows:

Unit-cell dimensions, angstroms

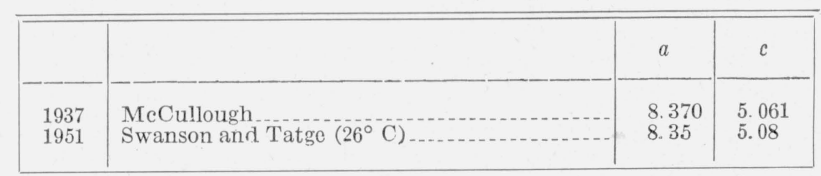

The material proved too unstable for a determination of the indices of refraction. The density is 4.16 . 
TABLE 6. Selenium dioxide: $\mathrm{SeO}_{2}$

\begin{tabular}{|c|c|c|c|c|c|}
\hline \multicolumn{3}{|c|}{$\begin{array}{l}1951 \text { Swanson and Tatge } \\
\mathrm{Cu}, 1.5405,26^{\circ} \mathrm{C}\end{array}$} & \multicolumn{3}{|c|}{$\begin{array}{l}1951 \text { Swanson and Tatge } \\
\mathrm{Cu}, 1.5405,26^{\circ} \mathrm{C}\end{array}$} \\
\hline$h k l$ & $d$ & 1 & $h k l$ & $d$ & 1 \\
\hline 110 & 5.92 & 13 & 322 & 1. 711 & \\
\hline 200 & 4. 17 & 85 & 500 & 1. 673 & 9 \\
\hline 210 & 3.73 & 100 & 510 & 1.640 & 9 \\
\hline 201 & 3.227 & 11 & 431 & 1. 588 & 3 \\
\hline 211 & 3.009 & 88 & 511 & 1. 559 & 14 \\
\hline 220 & 2. 998 & 38 & 332 & 1. 556 & 10 \\
\hline 300 & 2. 789 & 2 & 213 & 1. 538 & 4 \\
\hline 310 & 2. 640 & 14 & 422 & 1. 503 & 3 \\
\hline 002 & 2. 533 & 2 & 440 & 1. 478 & 4 \\
\hline 311 & 2. 343 & 3 & 530 & 1. 437 & 4 \\
\hline 112 & 2.320 & 15 & 313 & 1. 421 & 5 \\
\hline 202 & 2. 252 & 14 & 432 & 1. 394 & 8 \\
\hline 321 & 2. 105 & 6 & 512 & 1. 379 & 20 \\
\hline 400 & 2. 090 & 14 & $522\}$ & 1. 324 & 9 \\
\hline 330 & 1. 973 & 10 & $620\}$ & & \\
\hline 401 & 1. 933 & & & 1. 305 & 4 \\
\hline 411 & 1.895 & 14 & 413 & 1. 292 & 3 \\
\hline 420 & 1.871 & 14 & 621 & 1. 278 & 12 \\
\hline 312 & 1. 831 & 17 & 004 & 1. 264 & 15 \\
\hline 421 & 1. 755 & 13 & 612 & 1. 209 & 13 \\
\hline
\end{tabular}

\section{Mercuric Chloride, $\mathrm{HgCl}_{2}$}

One of the two patterns for mercuric chloride in the X-ray diffraction file of the American Society for Testing Materials was published in 1928 by Bräkken and Harang [25], the other by Hanawalt, Rinn, and Frevel [14] in 1938. Unfortunately, the Hanawalt, Rinn, and Frevel pattern is omitted from the index. Instead, the index lines 4.35, 3.00, 2.70 belonging to mercuric chloride are assigned to mercuric chlorate. (See "Alphabetical Index of X-ray diffraction patterns, covering original set of cards" for June 1945 , p. 53.) In table 7 the two patterns are compared with one more recently prepared at this Bureau. The Bräkken and Harang pattern was prepared with iron radiation for which a wavelength of 1.932 is given; for the Hanawalt, Rinn, and Frevel pattern molybdenum radiation with a wavelength 0.708 $k X$ was used. The NBS material was obtained from the J. T. Baker Chemical Co., No. 101742. Spectrographic analysis showed no impurity greater than 0.01 percent.

The data of Bräkken and Harang were published as a table of $h k l$ indices, $\sin ^{2} \theta$ values, and intensity values visually estimated. For our comparison table the $\sin ^{2} \theta$ values were converted to interplanar spacings, using the iron radiation wavelength 1.93597 A. The spacings of Hanawalt, Rinn, and Frevel were converted from $k X$ units to angstroms by applying the factor 1.002. The 120 line is the strongest for all three patterns. The second strongest is the 200 , but this line is not resolved from the 031 line by Hanawalt, Rinn, and Frevel, so that their intensity measurement is a combination of the two intensities. The 011 and 111 are third and fourth strongest in the Hanawalt, Rinn, and Frevel pattern, reversed for the NBS pattern. The difference in intensity is probably too small to be significant; it is not due to the radiation used, as the conversion factor for molybdenum to copper radiation is close to 1 in this range.
TABLE 7. Mercuric chloride: $\mathrm{HgCl}_{2}$

\begin{tabular}{|c|c|c|c|c|c|c|}
\hline \multirow[b]{2}{*}{$h k l$} & \multicolumn{2}{|c|}{$\begin{array}{c}1928 \\
\text { Bräkken and } \\
\text { Harang } \\
\text { Fe, } 1.936\end{array}$} & \multicolumn{2}{|c|}{$\begin{array}{c}1938 \\
\text { Hanawalt, Rinn, } \\
\text { and Frevel } \\
\text { Mo, } 0.709\end{array}$} & \multicolumn{2}{|c|}{$\begin{array}{c}1951 \\
\text { Swanson and } \\
\text { Tatge } \\
\mathrm{Cu}, 1.5405,26^{\circ} \mathrm{C}\end{array}$} \\
\hline & $d$ & $I$ & $d$ & $I$ & $d$ & $I$ \\
\hline 120 & 4. 34 & vs & 4. 36 & 100 & 4. 35 & 100 \\
\hline 011 & 4. 08 & $\mathrm{~s}$ & 4. 11 & 25 & 4.10 & 38 \\
\hline 021 & 3.57 & W & & & 3. 58 & 3 \\
\hline 101 & 3. 488 & w & & & & \\
\hline 111 & 3.368 & $\mathrm{~s}$ & 3.41 & 38 & 3.383 & 31 \\
\hline 040 & 3.172 & W & 3. 21 & 13 & 3. 188 & 11 \\
\hline 121 & 3. 056 & vw & -... & -.... & 3. 066 & 2 \\
\hline 031 & 3. 019 & W & 3.01 & 75 & 3.033 & 21 \\
\hline 200 & 2. 976 & $\mathrm{~s}$ & 3.01 & 75 & 2. 986 & 48 \\
\hline $\begin{array}{l}131 \\
220\end{array}$ & 2. 692 & $\mathrm{~s}$ & 2. 70 & 50 & 2. 707 & 36 \\
\hline 211 & 2. 403 & $\mathrm{~m}$ & 2.41 & 25 & 2. 420 & 14 \\
\hline 141 & 2. 348 & W & -.... & $\ldots$ & 2. 366 & 2 \\
\hline 221 & 2. 281 & vW & & & 2. 297 & 4 \\
\hline 051 & 2. 194 & $\mathrm{w}$ & 2.18 & 13 & 2. 182 & 6 \\
\hline 002 & 2. 158 & $\mathrm{VW}$ & $\ldots$ & .... & $\ldots$ & -.... \\
\hline $\begin{array}{l}012 \\
231\end{array}$ & 2.120 & $\mathrm{~m}$ & 2. 12 & 25 & 2. 132 & 9 \\
\hline 060 & & & & & & \\
\hline 151 & 2. 056 & $\mathrm{~m}$ & 2. 06 & 25 & 2. 065 & 13 \\
\hline 112 & 1. 997 & $\mathrm{~m}$ & 2. 00 & 50 & 2. 004 & 16 \\
\hline 241 & & -..- & 1.94 & 25 & 1. 940 & 11 \\
\hline 122 & 1. 929 & $\mathrm{~m}$ & & & & \\
\hline 061 & 1.895 & w & 1.90 & 13 & 1. 902 & 8 \\
\hline 132 & 1.829 & w & -... & - ..... & 1. 837 & 1 \\
\hline 301 & 1. 806 & vw & - & .... & 1. 810 & 1 \\
\hline $\begin{array}{l}042 \\
311\end{array}$ & 1. 784 & $\mathrm{~m}$ & 1. 79 & 13 & 1. 791 & 6 \\
\hline 251 & 1. 762 & w & - . & ..... & 1. 769 & 4 \\
\hline 202 & 1. 745 & $\mathrm{vW}$ & & & 1. 765 & 1 \\
\hline 071 & 1. 674 & vw. & 1.67 & 13 & 1. 666 & 4 \\
\hline 331 & 1. 658 & w & - & , . & - & - \\
\hline 052 & 1. 643 & $\mathrm{~m}$ & & & & \\
\hline 232 & & .... & 1. 62 & 13 & 1. 619 & 3 \\
\hline 080 & 1. 589 & $\mathrm{~m}$ & 1.59 & 13 & 1. 595 & 1 \\
\hline 341 & 1. 569 & vw & - & $\ldots$ & 1. 572 & 1 \\
\hline 180 & 1. 531 & $\mathrm{~m}$ & 1. 54 & 13 & 1. 539 & 2 \\
\hline 081 & 1. 489 & w & & & 1. 496 & 1 \\
\hline 312 & ..... & -... & 1.455 & 13 & 1. 454 & 4 \\
\hline 013 & ..... & -... & ..... & ..... & 1. 431 & 1 \\
\hline 023 & $\ldots$ & ... & - & .... & 1. 406 & 3 \\
\hline
\end{tabular}

In indexing the pattern the unit-cell dimensions were taken in the Dana convention, $c<a<b$, although the reverse order is given by Wyckoff [8]. The unit cell dimensions published in 1934 by Braekken and Scholten [26], 5.963, 12.735, 4.325, converted from $k X$ to angstroms compare thus with those derived from the NBS pattern:

Unit-cell, angstroms

\begin{tabular}{|c|c|c|c|c|}
\hline & & $a$ & $b^{\circ}$ & $c$ \\
\hline $\begin{array}{l}1934 \\
1951\end{array}$ & $\begin{array}{l}\text { Braekken and Scholten } \\
\text { Swanson and Tatge }\left(26^{\circ} \mathrm{C}\right)\end{array}$ & $\begin{array}{l}5.975 \\
5.96\end{array}$ & $\begin{array}{l}12.761 \\
12.76\end{array}$ & $\begin{array}{l}\text { 4. } 334 \\
4.32\end{array}$ \\
\hline
\end{tabular}

The presence of $h k 0$ lines only for $k$ even, and $h 0 l$ lines only for $h+l$ even, agrees with the generally accepted orthorhombic space-group determination $D_{2 h}^{16}(P m n b)$ for the crystal orientation used here. The density of the material calculated from the NBS $\mathrm{X}$-ray data is $D=5.49$. The indices of refraction are very high. 


\section{Magnesium Silicate, $\mathrm{Mg}_{2} \mathrm{SiO}_{4}$}

A sample of magnesium silicate (forsterite) of high purity, labeled $\mathrm{X}-9$, was furnished by the Radio Corporation of America. It was prepared in connection with their phosphor project [12], by heating at $1,500^{\circ} \mathrm{C}$ for $1 \mathrm{hr}$. The indexed pattern is compared in table 8 with a pattern published by Clark [27] in 1946. Clark's pattern was made with cobalt radiation, for which he specified a wavelength of $1.786 \mathrm{~A}$ $(k X)$, that of the NBS with copper, of wavelength $1.54050 \mathrm{~A}$. The large unit cell of magnesium silicate furnishes a large number of possible planar reflections. Thus indexing becomes increasingly difficult with increasing Bragg angle. As $\theta$ increases, Clark's interplanar spacings diverge more and more widely from calculated values. The last 17 lines of his pattern were omitted from the table because the divergence combined with the multiplicity of possible lines makes indexing purely arbitrary. The Geiger-counter intensity measurements of the NBS pattern show 112 to be the strongest line, 131 second, and 222 third, rather than the order 222, 131, and 112 estimated by Clark.

TABLE 8.

Magnesium silicate: $\mathrm{Mg}_{2} \mathrm{SiO}_{4}$

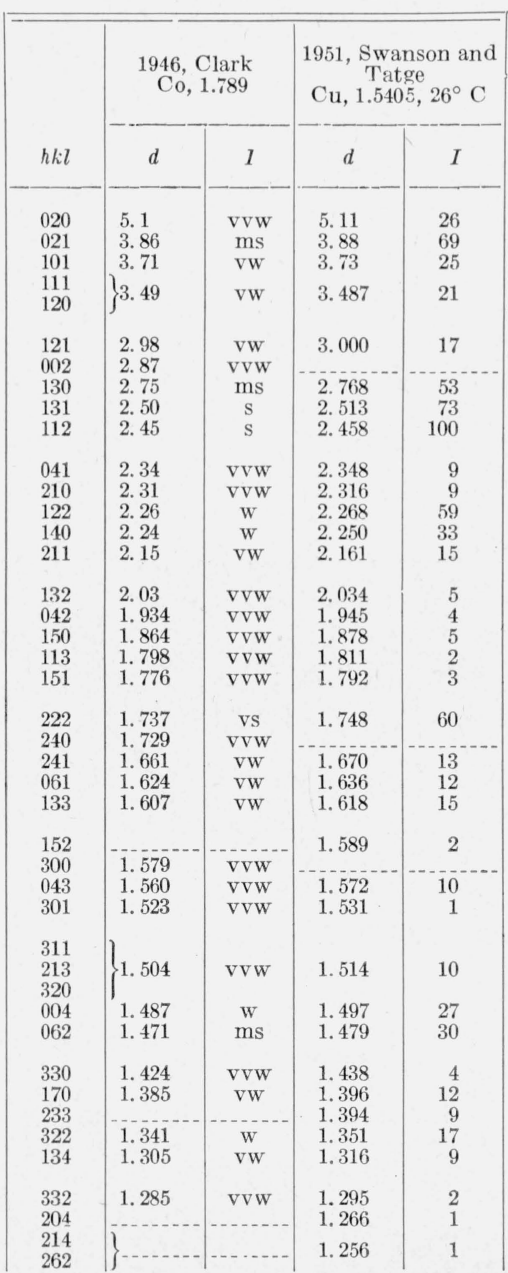

Magnesium silieath: $\mathrm{Mg}_{2} \mathrm{SiO}_{4}$ - Con.

\begin{tabular}{|c|c|c|c|c|}
\hline \multirow[b]{2}{*}{$h k l$} & \multicolumn{2}{|c|}{$\begin{array}{c}\text { 1946, Clark Co, } \\
1.789\end{array}$} & \multicolumn{2}{|c|}{$\begin{array}{c}\text { 1951, Swanson and } \\
\text { Tatge } \\
\mathrm{Cu}, 1.5405,26^{\circ} \mathrm{C}\end{array}$} \\
\hline & $d$ & $I$ & $d$ & 1 \\
\hline $\begin{array}{l}163 \\
081\end{array}$ & & & 1. 246 & 2 \\
\hline $\begin{array}{l}270 \\
2751\end{array}$ & & & 1. 242 & 2 \\
\hline 400 & 1.181 & $\mathrm{VvW}$ & $\begin{array}{l}\text { 1. } 180 \\
\text { l. }\end{array}$ & 1 \\
\hline $\begin{array}{l}401 \\
352 \\
272\end{array}$ & $\begin{array}{c}1.159 \\
1.148 \\
\text { (a) }\end{array}$ & $\begin{array}{l}\mathrm{vvw} \\
\mathrm{vVw}\end{array}$ & $\begin{array}{l}\text { 1. } 166 \\
\text { 1. } 155 \\
1.1476\end{array}$ & $\begin{array}{l}2 \\
1 \\
1\end{array}$ \\
\hline $\begin{array}{l}263 \\
421\end{array}$ & & & 1. 1369 & 2 \\
\hline $\begin{array}{l}430 \\
412\end{array}$ & & & 1. 1225 & 1 \\
\hline $\begin{array}{l}412 \\
334\end{array}$ & & 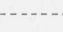 & 1. 0987 & 1 \\
\hline $\begin{array}{l}534 \\
055 \\
055\end{array}$ & & & 1. 0360 & 3 \\
\hline 0.10 .0 & & & 1. 0201 & 3 \\
\hline $\begin{array}{r}283 \\
381\end{array}$ & & & 0.9797 & 1 \\
\hline $\begin{array}{l}381 \\
462\end{array}$ & & & & 1 \\
\hline $\begin{array}{r}414 \\
2\end{array}$ & & & .9266 & 1 \\
\hline 2.10 .1 & & & & \\
\hline $\begin{array}{l}531 \\
444\end{array}$ & & & $\begin{array}{r}.9061 \\
.8748\end{array}$ & $\begin{array}{l}1 \\
1\end{array}$ \\
\hline $\begin{array}{l}3.10 .1 \\
0.12 .0\end{array}$ & & & .8495 & 1 \\
\hline $\begin{array}{l}533 \\
326\end{array}$ & & & & \\
\hline $\begin{array}{l}326 \\
365\end{array}$ & & & .8331 & 7 \\
\hline $\begin{array}{r}552 \\
\end{array}$ & & & & \\
\hline $\begin{array}{r}1.5 \\
037\end{array}$ & $\cdots$ & & .8281 & 9 \\
\hline
\end{tabular}

a The remaining 17 lines could not be indexed and are omitted.

Although several sets of unit-cell dimensions are available for the closely related mineral olivine (iron-bearing), only one was found for forsterite. Rinne [28] in 1923 examined a natural forsterite from Vesuvius, for which he found the dimensions $a=4.74$, $b=10.26, \quad c=5.99$, using molybdenum radiation, wavelength $0.7076 \mathrm{~A}$, which compares very closely with olivine measurements. Converting from $k X$ to angstrom units, his values compare with those derived from the NBS pattern thus:

Unit cell, angstroms

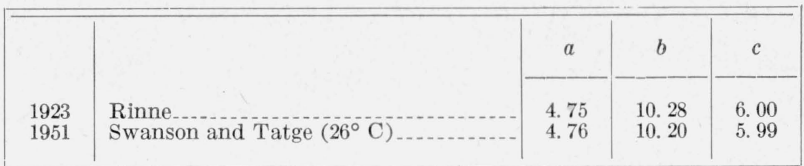

From the NBS data the cell dimensions were calculated only from spacings of planes parallel to one or more axes.

Forsterite is orthorhombic with a space group presumably the same as that specified by Bragg and Brown [29] for olivine, $V_{h}^{16}$, or $D_{2 h}^{16}$ (Pnma). The density calculated from the cell dimensions of the NBS determination, allowing four molecules per unit cell, is 3.213 . The material was too finely powdered for us to determine the indices of refraction. 


\section{Magnesium Tungstate, $\mathrm{MgWO}_{4}$}

Five patterns of magnesium tungstate are compared in table 9. Two are by Broch [30], published in 1928 and 1930, one by Fonda [31], 1944, and one by Dunning and Megaw [32], 1946. To Broch we owe most of the indices. He used copper radiation for the first pattern, iron for the second. In addition to the indices his data include diffraction, angles and, for the second pattern, estimated intensities. The interplanar spacings listed in table 9 were computed from his reflection angles with recent wavelength values, so that they appear in angstroms. Fonda used molybdenum radiation, other workers copper. The Fonda and the Dunning and Megaw interplanar spacings are converted from presumed $k X$ units to angstroms. For the NBS pattern, material of exceptionally high purity was obtained from the Radio Corporation of America, marked No. 4, prepared at $1,000^{\circ} \mathrm{C}$. The NBS pattern includes the first accurately measured intensities.

Table 9. Magnesium tungstate: $\mathrm{MgWO}_{4}$

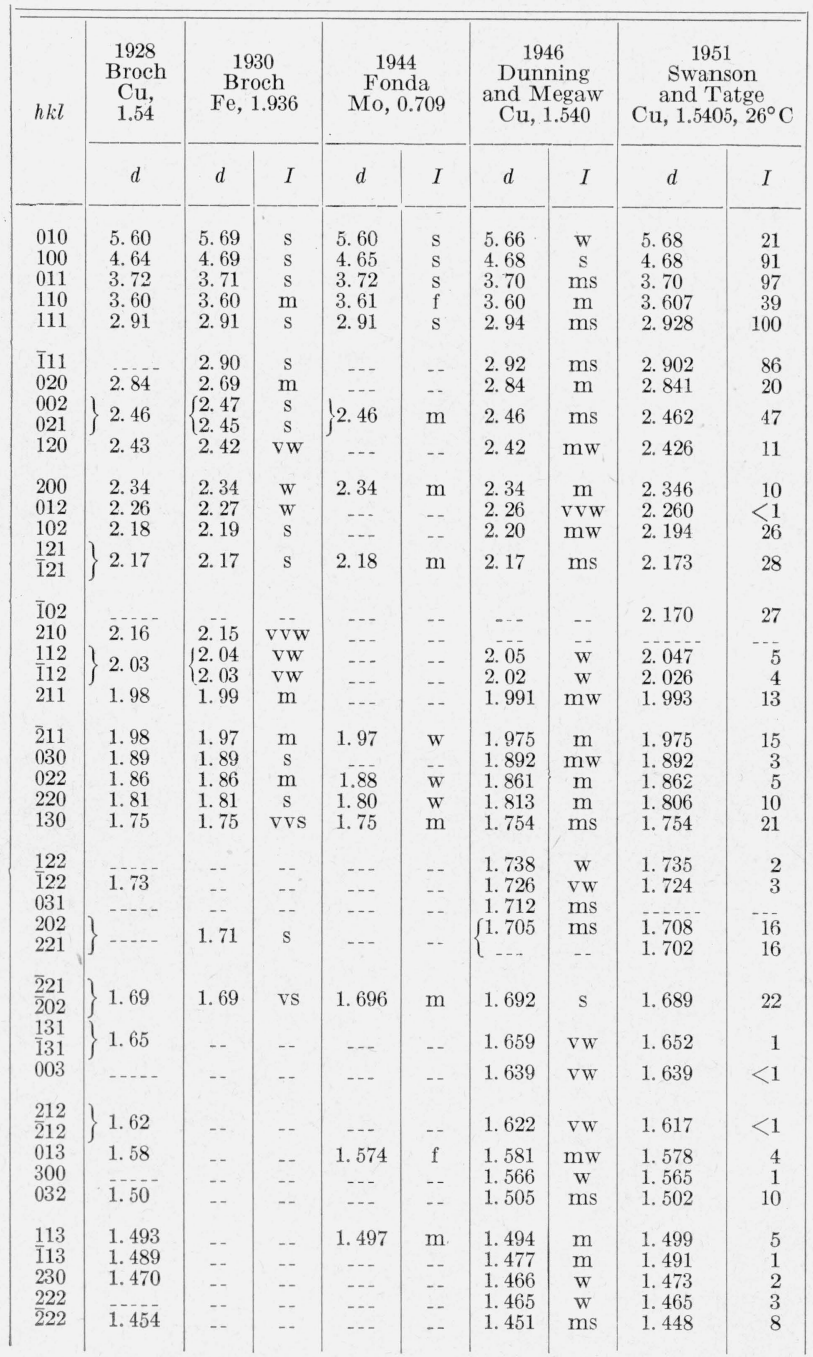

TABLE 9. Magnesium tungstate: $\mathrm{MgWO}_{4}$-Continued

\begin{tabular}{|c|c|c|c|c|c|c|c|c|c|}
\hline \multirow[b]{2}{*}{$h k l$} & \multirow{2}{*}{$\begin{array}{c}1928 \\
\text { Broch } \\
\text { Cu, } \\
1.54 \\
\\
d\end{array}$} & \multicolumn{2}{|c|}{$\begin{array}{c}1930 \\
\text { Broch } \\
\text { Fe, } 1.936\end{array}$} & \multicolumn{2}{|c|}{$\begin{array}{c}1944 \\
\text { Fonda } \\
\text { Mo, } 0.709\end{array}$} & \multicolumn{2}{|c|}{$\begin{array}{c}1946 \\
\text { Dunning } \\
\text { and Megaw } \\
\mathrm{Cu}, 1.540\end{array}$} & \multicolumn{2}{|c|}{$\begin{array}{c}1951 \\
\text { Swanson } \\
\text { and Tatge } \\
\mathrm{Cu}, 1.5405,26^{\circ} \mathrm{C}\end{array}$} \\
\hline & & $d$ & $I$ & $d$ & $I$ & $d$ & $I$ & $d$ & $I$ \\
\hline $\begin{array}{l}311 \\
311\end{array}$ & 1. 438 & -- & - & -. & -- & 1. 438 & $\mathrm{~ms}$ & 1. 434 & 13 \\
\hline 132 & 1. 428 & -. & -. & 1. 427 & $\mathrm{~m}$ & 1. 427 & $\mathrm{~ms}$ & 1. 426 & 10 \\
\hline 132 & 1. 426 & -. & -. & & -- & -.. & -. & 1. 423 & 12 \\
\hline 320 & 1.365 & -. & -. & 1. 365 & W & ... & -. & 1. 364 & 5 \\
\hline 041 & 1. 363 & -. & -- & -.. & -- & -. & -- & -..... & --- \\
\hline $\begin{array}{l}302 \\
321\end{array}$ & 1. 320 & -. & -. & ... & -- & ... & -. & 1. 325 & 1 \\
\hline$\frac{321}{302}$ & 1. 315 & -. & - & -- & -- & -. & -- & 1. 317 & 1 \\
\hline $\begin{array}{l}141 \\
141 \\
213\end{array}$ & 1. 309 & -- & -. & 1. 313 & $\mathrm{~m}$ & -. & -. & 1. 311 & 5 \\
\hline 213 & 1. 306 & -- & -. & -.. & -- & -. & -- & & \\
\hline 232 & $\ldots$ & -. & -. & -.- & -. & -.- & - & 1. 269 & 2 \\
\hline $\begin{array}{l}\overline{2} 32 \\
004\end{array}$ & 1. 261 & -. & -. & 1. 262 & $\mathrm{f}$ & -.. & -. & 1. 260 & 1 \\
\hline $\begin{array}{l}004 \\
223\end{array}$ & 1. 215 & -. & -- & $\cdots$ & -- & -. & -- & 1. 231 & 1 \\
\hline$\overline{2} 23$ & 1. 211 & -. & 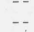 & - & - & ... & -- & - & -.. \\
\hline 330 & 1. 202 & -. & $\therefore$ & 1. 204 & f & ... & - & 1. 206 & 3 \\
\hline $\begin{array}{l}322 \\
322\end{array}$ & 1. 1933 & -- & -- & -. & -- & -. & -- & - & $\cdots$ \\
\hline 142 & $\ldots$ & -. & -. & -.. & -. & $\ldots$ & -- & 1. 1897 & 1 \\
\hline $\begin{array}{l}142 \\
241\end{array}$ & 1.1776 & -- & -. & 1. 177 & f &.- & -- & $\begin{array}{l}1.1805 \\
1.1778\end{array}$ & 2 \\
\hline$\overline{2} 41$ & 1. 1764 & & & & & & & & \\
\hline 400 & $-\ldots$ & - & - & $\ldots$ & -. & -.. & -- & 1. 1743 & 1 \\
\hline 050 & & -. & -. & -.. & .. & .. & -- & 1. 1397 & 1 \\
\hline $\begin{array}{l}024 \\
411\end{array}$ & 1. 1273 & -- & - & -- & -- & -. & -- & - & -.. \\
\hline$\frac{411}{411}$ & 1. 1149 & -. & -- & 1.114 & f & -. & -- & 1.1186 & 1 \\
\hline 150 & 1. 1019 & -. & -. & 1. 102 & f & ... & -- & 1. 1034 & 3 \\
\hline $\begin{array}{l}124 \\
124\end{array}$ & 1. 0960 & -. & -. & -.. & -- & -.. & -- & 1. 0987 & 1 \\
\hline 420 & 1. 0818 & -. & .. & 1. 080 & $\mathrm{f}$ & -.. & .. & 1. 0853 & $<1$ \\
\hline 043 & 1. 0726 & -- & -- & - . & -. & -.. & -. & 1. 0768 & 1 \\
\hline
\end{tabular}

The unit-cell constants of the monoclinic magnesium tungstate crystals were given by Broch from his first pattern as $a=4.67, b=5.66, c=4.92, \beta=$ $89^{\circ} 35^{\prime}$, from his second pattern as $a=4.68, b=5.66$, $c=4.93, \beta=89^{\circ} 40^{\prime}$. Converted from $k X$ to angstroms, the later values compare with those derived from the NBS pattern thus:

Unit cell, angstroms

\begin{tabular}{|c|c|c|c|c|}
\hline & 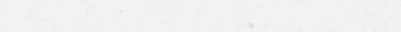 & $a$ & $b$ & $c$ \\
\hline $\begin{array}{l}1930 \\
1951\end{array}$ & $\begin{array}{l}\text { Broch } \\
\text { Swanson and Tatge }\left(26^{\circ} \mathrm{C}\right)\end{array}$ & $\begin{array}{l}4.69 \\
4.69\end{array}$ & $\begin{array}{l}5.67 \\
5.68\end{array}$ & $\begin{array}{l}4.94 \\
4.92\end{array}$ \\
\hline
\end{tabular}

Broch's 1930 paper gives the space group as $C_{2 h}^{4}(P 2 / c)$ two molecules in the unit cell; the NBS pattern conforms to this determination. The density calculated from the NBS data is 6.897. The material was too finely powdered to work with satisfactorily in determining the indices of refraction, but it is known that they are very high.

\section{References}

[1] American Society for Testing Materials, X-Ray Diffraction Data Cards, Philadelphia, Pa. (1939?); first supplement (1944); second edition, including second supplement (1950). For a description of this file see Bull. Ám. Soc. Testing Materials No. 135, 64 (1945); No. 160, 18 (1949). 
[2] H. Friedman, Geiger-counter spectrometer for industrial research, Electronics 18, 132 (1945).

[3] Eric R. Jette and Frank Foote, Precision determination of lattice constants, J. Chem. Phys. 3, 605 (1935).

[4] H. van Bergen, Präzisionsmessung von Gitterkonstanten mit einer Kompensationsmethode II, Ánn. Phys. 39, 553 (1941).

[5] Kathleen Lonsdale, Divergent-beam X-ray photography, Nature 153, 22 (1944).

[6] National Bureau of Standards Applied Mathematics Series 10, Tables for conversion of X-ray diffraction angles to interplanar spacing. (Government Printing Office, Washington, D. C., 1950.)

[7] Ludo K. Frevel, Chemical analysis by powder diffraction, Ind. \& Eng. Chem., Ánal. Ed. 16, 209 (1944).

[8] Ralph W. G. Wyckoff, The structure of crystals, 2d ed., (The Chemical Catalog Company, Inc., New York, N. Y., 1931); Supplement (Reinhold Publishing Corp., New York, N. Y., 1935); Crystal structures (Interscience Publishers Inc., New York, N. Y., 1948).

[ [9] Strukturbericht (Akademische Verlagsgesellschaft M. B. H., Leipzig).

[10] Chemical abstracts (American Chemical Society, Easton, $\mathrm{Pa}$.).

[11] The conversion factor for $\mathrm{kX}$ units to angstrom units, J. Sci. Inst. 24, 27 (1947).

[12] H. W. Leverenz, Phosphors versus the periodic system of the elements, Proc. Inst. Radio Engineers 32, 256 (1944).

[13] L. Vegard, Die Struktur der isomorphen Gruppe $\mathrm{Pb}\left(\mathrm{NO}_{3}\right)_{2}, \mathrm{Ba}\left(\mathrm{NO}_{3}\right)_{2}, \mathrm{Sr}\left(\mathrm{NO}_{3}\right)_{2}, \mathrm{Z}$. Phys. 9, 395 (1922).

[14] J. D. Hanawalt, H. W. Rinn, and L. K. Frevel, Chemical analysis by $\mathrm{X}$-ray diffraction; classification and use of X-ray diffraction patterns, Ind. \& Eng. Chem., Ánal. Ed. 10, 457 (1938)

[15] F. M. Jaeger and F. A. van Melle, On the symmetry and structure of the cubic nitrates of calcium, strontium, barium, and lead, Akad. Wetens. Amsterdam, Proc. Sec. Sci. 31, 651 (1928).

[16] H. Th. Ringdal, Úber Mischkristalle von Erdalkalinitraten, Z. Krist. 82, 50 (1932).

[17] L. Vegard and K. I. Roer, Verfahren zur röntgenometrischen Bestimmung des Temperatureinflusses auf Kristallgitter mit Verwendung auf Nitraten zweiwertiger Metalle, Avhandl. Norske Vidensk.-Ákad. Oslo I, Mat.-Naturv. Klasse 1941, No. 17 (1942).
[18] L. Vegard and Leif Bilberg, Die Kristallstruktur der Nitrate von $\mathrm{Ca}$, Sr. $\mathrm{Ba}$ und $\mathrm{Pb}$, Avhandl. Norske Vidensk.-Ákad. Oslo, I, Mat.-Naturv. Klasse 1931, No. 12,22 pp. (1932)'

[19] W. Nieuwenkamp and J. M. Bijvoet, Die Kristallstruktur von Bleifluochlorid $\mathrm{PbFCl}, \mathrm{Z}$. Krist. 81, 469 (1932).

[20] W. Nieuwenkamp, Die chemische Zusammensetzung von Matlockite, Z. Krist. 86, 470 (1933).

[21] L. K. Frevel, H. W. Rinn, and H. C. Anderson, Tabulated diffraction data for tetragonal isomorphs, Ind. \& Eng. Chem., Anal. Ed. 18, 83 (1946).

[22] F. A. Bannister, The erystal structure and optical properties of matlockite $(\mathrm{PbFCl})$, Miner. Mag. 23, 587 (1934).

[23] James D. McCullough, The crystal structure of selenium dioxide, J. Am. Chem. Soc. 59, 789 (1937).

[24] G. R. Waitkins and C. W. Clark, Selenium dioxide preparation, properties and use as oxidizing agent, Chem. Rev. 36, 235 (1945).

[25] H. Bräkken and L. Harang, Zur Kristallstruktur einiger rhombischer Verbindungen $\mathrm{MX}_{2}$; I, Z. Krist. 68, 123 (1928).

[26] H. Braekken and W. Scholten, Die Kristallstruktur des Quecksilber Chlorids $\mathrm{HgCl}_{2}, \mathrm{Z}$. Krist. 89, 448 (1934).

27] C. Burton Clark, X-ray diffraction data for compounds in the system $\mathrm{CaO}-\mathrm{MgO}-\mathrm{SiO}_{2}, \mathrm{~J}$. Am. Ceramic Soc. 99, 25 (1946).

[28] F. Rinne, Bemerkungen und röntgenographische Erfahrungen über die Umgestaltung und den Zerfall von Kristallstrukturen, Z. Krist. 59, 230 (1923).

[29] W. L. Bragg and G. B. Brown, The structure of olivine, Z. Krist. 63, 538 (1926).

[30] Einar Broch, Ưber die Gitterart einiger monoklinen Verbindungen vom Typus $\mathrm{MgWO}_{4}, \mathrm{Z}$. Phys. Chem. [B] 1, 409 (1928); Untersuchungen über Kristallstrukturen des Wolframittypus und des Scheelittypus, Skrifter Norske Videns.-Akad. Oslo I, Mat.-Nat. Klasse 1929, No. 8 (1930).

[31] Gorton R. Fonda, The magnesium tungstate phosphor, J. Phys. Chem. 48, 303 (1944)

[32] N. J. Dunning and Helen D. Megaw, The crystal structure of magnesium tungstate, Trans. Faraday Soc. 42, 705 (1946).

Washington, October, 31, 1950. 